\title{
Moral or Authoritative Leadership: Which One is Better for Faculty Members?
}

\author{
Bilal Afsar* \\ School of Management, Asian Institute of Technology, Bangkok, Thailand \\ *Corresponding author: afsarbilal@yahoo.com
}

Received May 15, 2014; Revised July 07, 2014; Accepted September 04, 2014

\begin{abstract}
While much has been written and empirically researched about leadership style, little effort has been made to make out what constitutes successful and effective leadership for university teachers of Pakistan. Paternalistic leadership is a promising body of research that has been tailored to the Pakistani context in this study. The research focuses on the impact of two most important dimensions of paternalistic leadership on the commitment and organization citizenship behavior of university teachers of Pakistan. A questionnaire was used in this research to survey the relationship among moral and authoritative leadership behaviors, organization citizenship behavior and organization commitment. Data was obtained from 798 faculty members from thirteen public sector universities of Pakistan. We found that: (i) morality increased teacher's affective and continuance organization commitment, whereas authoritarianism negatively influenced the affective commitment; and (ii) morality positively affected the organization citizenship behavior and authoritarian paternalistic leadership negatively affected citizenship behavior.
\end{abstract}

Keywords: paternalistic leadership, affective commitment, continuance commitment, educational leadership, organization citizenship behavior

Cite This Article: Bilal Afsar, "Moral or Authoritative Leadership: Which One is Better for Faculty Members?.” American Journal of Educational Research, vol. 2, no. 9 (2014): 793-800. doi: 10.12691/education-2-9-14.

\section{Introduction}

Paternalistic leadership (PL) has received growing interest from organizational researchers around the world in the past two decades (e.g., Aycan, 2006; Blase \& Anderson, 1995; Cerit, 2010 Farh \& Cheng, 2000; Harris, 2004; Joo \& Park, 2010; Pellegrini \& Scandura, 2006). Paternalistic leadership is a leadership style that combines strong discipline, obedience and authority with fatherly benevolence, munificence and moral integrity. Farh \& Cheng (2000) showed that moral and authoritarian paternalistic leadership had strongest impact on job attitudes of employees such as loyalty, commitment, performance, trust, citizenship behavior and leader-member exchange.

The importance of paternalistic leadership in increasing the commitment of employees to supplement the organizational performance has been studied in many previous studies (Chan, Huang, Snape \& Lam, 2012; Chen, Tsui \& Farh, 2002; Erben \& Güneser, 2008; Hakanen, Bakker \& Schaufeli, 2006; Pellegrini \& Scandura, 2006, 2008; Pellegrini, Scandura, \& Jayaraman, 2010; Soylu, 2011). However, there has been minimal research on the impact of paternalistic leadership on commitment level and organizational citizenship behaviors of university's faculty members.

Paternalistic leadership makes employees work with better devotion, commitment, motivation, productive work behaviors, psychological contract, intent to stay in the organization, job satisfaction and attitudes beneficial for the success of the organizations (Anderman, 1991; Collins, 2010; Farh \& Cheng, 2000; Maryam \& Afsar, 2012; Min, $\mathrm{Xu}$, Jiuping, Hong \& Kan, 2007; Pellegrini \& Scandura, 2008; Schriesheim, Neider \& Scandura, 1998; Wang, Law, Hackett \& Chen, 2005). Farh et al. (2006) studied three constituent dimensions (moral leadership, benevolence leadership and authoritarian leadership) separately and proposed that moral leadership had the strongest positive predictive power on employee performance among the three styles of paternalistic leadership whereas authoritarian leadership had the strongest negative impact. They suggested that benevolence leadership is embedded in moral style of paternalism and future research could focus on the effect of moral and authoritarian paternalistic leadership.

Moral leadership conforms to the Chinese Confucian ideology that leaders are particularly expected to demonstrate high morality, superior personal virtues, selfdiscipline and unselfishness. Moral leadership is applied more often in non-western societies as the dominant notion of the culture in these countries is submission, conformance and obedience (Allen \& Meyer, 2011). Paternalism yields effective results in increasing motivation level of employees in collectivist cultures. As the research area of the current study is also rooted in collectivist culture, we argue that paternalistic leadership may explain employee's organizational commitment and engagement into citizenship behaviors and further our understanding of the role of paternalism in making teachers committed.

Paternalistic leaders have been highly respected throughout eastern societies. These leadership behaviors 
are regarded as essential and critical for effectiveness because the legal systems and institutional norms are still evolving in non-west countries (Cohen, 2007). Past research has shown that moral leadership is highly related to satisfaction with the leader, obedience and loyalty to the leader, organizational commitment, job performance and OCBs (Belisle, 2004; Kamper, 2008; Mascall, Leithwood, Straus \& Sacks, 2008). Inspired by Cheng et al.'s study (2004) indicating that the supervisors' moral leadership leads to responses of respect and identification from the subordinates, we expect to propose alternative psychological mechanisms to explain the effect of moral leadership on three distinct dimensions of organization commitment (affective, normative, and continuance commitment) and its effect on organization citizenship behaviors of employees individually, as well as on the overall organization.

Most of these researches were carried in the east due to the fact that in eastern societies employees are more submissive due to cultural, economic, social, demographic and political factors (Militello \& Berger, 2010). However some of the research studies have also highlighted the pivotal role of paternalistic leadership style to increase performance of employees in the western societies (Dabos \& Rousseau, 2004; Feather \& Rauter, 2004). PL style of management is significantly applicable to academic institutions because teachers like to work under flexible, moral, benevolent and caring leaders (Janelle \& Jon, 2010). However there has been no research on the universities of Pakistan, and taking into account the relevance and importance of PL management style. The second area of this study which has not been addressed previously is the impact of moral and authoritarian paternalistic leadership on employee's citizenship behavior at the individual as well as the organizational level.

\section{Theoretical Framework Hypotheses}

\subsection{Paternalistic Leadership and Organization Commitment}

Accumulated research has shown that paternalistic leadership is not a unified construct; rather, it consists of three dimensions-authoritarianism, benevolence, and morality (Blackmore, 2005; Farh \& Cheng, 2000; Foster, 2005; Wren, 2005). Authoritarianism refers to a leader's behavior of asserting strong authority and control over subordinates and demanding unquestioned loyalty, submission and obedience from them. The managers often endorse these values by setting up centralized and autocratic structures and by assuming a father-like role with a direct and authoritative leadership style (Meyer, Stanley, Herscovitch \& Topolnytsky, 2002; Liu, Siu \& Shi, 2010). Benevolence implies that a leader demonstrates individualized, holistic concern for subordinates' personal and familial well-being. Morality is broadly depicted as a leader's behavior that demonstrates superior moral character and integrity through acting unselfishly and leading by example.

The current researches showed that leaders usually do not display benevolence quite often and therefore benevolence had no significant impact on employee's commitment and other job outcomes (Rhea, 1968). The holistic concerns for employees are not shown by the leaders of small businesses as they are too busy in other vital matters of the organization and they consider benevolence less important than moral and authoritarian leadership (Henderson, 2008; Suazo, 2009). In general, paternalistic leaders take on a father-like role and provide protection and care for their employees' professional and personal lives in exchange for loyalty and compliance (Pellegrini \& Scandura, 2008).

Several studies conducted by Farh, Cheng, Chou and Chu (2006) have reported that eastern workers place a high value on paternalistic leadership style of being managed and prefer to be in the follower mode taking orders and obeying them because they feel these orders are for the betterment of their professional life as well as their private lives (Cohen, 2006). PL applies to Pakistani context because most of the workers are obedient to their leaders and prefer follower role (Law, 2009; Suazo, 2009). In PL, a leader must express, under the atmosphere of ruling by people, father's benevolence, dignity, control, personl example of a role model and morally unselfishness. Therefore, PL is closer to the eastern societies and enterprises than the other western leadership styles (Eden, 1998; Van, 2006).

Paternalistic leadership is considered to be the important factor in organizational behavior and leadermember relationship (Chu \& Hung, 2009; Geijsel, Sleegers, Leithwood \& Jantzi, 2003; Schroeder, 2011), organizational citizenship performance and affective and continuance commitment (Chu \& Hung, 2009), organizational conflict (Huery, Hsin \& Chiou, 2008), subordinated pressure and intent to quit (Sun, 2010), and upward communication and team cohesion (Chang \& Chao, 2008; Chu \& Hung, 2009). Farh and Cheng's (2000) suggest that authoritarian style of leadership seeks reliance and obedience from the workers which result in improved commitment and job satisfaction; and moral leadership results in value and recognition which is pivotal for display of citizenship behavior among workers of the organization.

Guest (2004) pointed out the role and significance of paternalistic leadership in creating a workforce who is committed and is taught to believe in the value of remaining loyal to one's organization. Though, some researchers (Chou, 2006; Mudulia, 2012; Organ \& Ryan, 1995; Pasa, Kabasakal \& Bodur, 2001), after studying a number of empirical researches on organizational behavior and organization commitment within Taiwanese enterprises, highlighted that modern human resource management has stimulated the concept of conformist personnel management to a recent one of human resource enlargement, which emphasizes the connotation of workers giving their best to the organization where they have challenging tasks that would add to their experience, but it would need to do it voluntarily and in their own time investing personal time and effort (Asare, 2011).

A paternalistic leader would know that an operation is consuming the company resources, but this is not within subordinates' direct responsibility. Despite knowing about constraints, paternalistic leaders are concerned about employees. They encourage employees to find purpose in the organization and integrate with organizational values; 
only then employees feel themselves as a part of the organization; and when someone talks negatively about the company or its services to the customers, they would defend the company, and prove him wrong. Joo and Park (2010) in the study of 217 employees of 105 companies found that leader authoritative behavior has negative connection with affective commitment. Moral leadership is setting a personal example of grace, role model, fair and just and it increases loyalty and positive citizenship behavior (Ha \& Choi, 2002). Collins (2010) and Cheng et al. (2002) suggest that paternalistic practices benefits organization by increasing overall commitment.

Paternalism is a prevailing cultural trait of conventional eastern societies such as China, Japan, India, and Korea (Kurnianingsih, Yuniarti, \& Kim, 2012).Paternalism can be explained in different context like social, organizational, cultural and personal relationship. From the perspective of organizational relationship we take leader with positive attitude due to fatherly concern for the followers as an important strategic human resource practice which will make employees loyal and dedicated (Turnley, Bolino, Lester \& Bloodgood, 2003). In today's competitive world, most of the organizations face the problem of employee turnover which leaves managers in a fix as they have to search for new employees, invest resources in recruitment and selection, work hard in training and developing them, getting them used to the organization culture and then making them loyal and motivated all requires a lot of resources (Robinson \& Rousseau, 1994).

If employees become disinterested due to coercion and lack of flexibility, it leads to lack of commitment which ultimately defects the employees from the organization and in today's fiercely competitive world losing a chunk of good employees is a big loss for the organization's managers (Coyle \& Neuman, 2004).So the managers have to come up with a style of leadership that can keep employees committed and on their toes all the time. From the organization perspective 'new paternalism' is assessed as improving and civilizing workplace, 'new paternalism' companies are more concerned into personal lives of their employees and supporting them in their family's issues. So due to this concern and caring attitude by subordinate towards their employee increase their dedication and loyalty.

Gwavuya (2011) argued that the new paternalism brings out employee loyalty, efficiency, and promote team-work output (Aycan, 2001). Allen and Meyer (2011) describe organization commitment like a multidimensional construct. So, organizational commitment has three types: namely affective, normative, and continuance commitment. Affective commitment (AC) is 'how much employee is emotionally attached and involved and drawn in to the organization while normative commitment is sense of responsibility to employment and sincerity to the profession (Cheng et al., 2004). Lastly, continuance commitment (CC) is an understanding of the costs and overheads linked with quitting the organization, each of them is contributing to the employee's relationship toward the organization (Lin, 2005). The definition of organizational commitment can vary depending on researchers and construction and validation of models (Irawanto, 2011).

Causes of normative commitment are the promotion opportunities, training and development provided for the employees, career counselling and other long-term investments that are done by the organization (Feather \& Rauter, 2004). Moral leadership behaviors does affect the normative commitment of the employee because the employee feels an obligation to stay at the organization because of a sense of duty, expectation of the supervisor, ethical climate and loyalty to moral obligation(Sagie, 1998; Brooks, 2003). It may be expected that authoritarian leadership behaviors lead to OC because of fear. According to the descriptions above, the following hypothesis can be stated:

Hypothesis 1: Paternalistic leadership influences affective and continuance organizational commitment. H1a: Moral paternalistic leadership positively influences affective organizational commitment and continuance organizational commitment.

H1b: Authoritarian paternalistic leadership negatively influences affective organizational commitment and continuance organizational commitment.

\subsection{Paternalistic Leadership and Organizational Citizenship Behaviour}

Organizational citizenship behaviour has been defined as participating in activities or actions that are not formally a part of the job description, but are beneficial for the the organization as a whole (Dyne, Graham \& Dienesch, 1994). Thus, OCBs are non-compulsive, discretionary and constructive behaviors that are directed to the organization or to its members (Newland, 2012; Podsakoff \& MacKenzie, 1994). Even though OCB is not part of the individual's assigned duties or formal reward system, these extra-role behaviors still contribute positively to the organization effectiveness, as it helps in getting long term organizational success by contributing to psychological and social conditions of organization, its members and the employees themselves (Wijayanto \& Kismono, 2004).

In recent years, researchers have recognized the importance of distinguishing between in-role (e.g. sales volume, tasks, commissions, percentage quota) and extrarole (e.g. organizational citizenship behaviors, pro-social behaviors) aspects of performance (Jain, Giga \& Cooper, 2013). The types of extra-role and non-task related work behaviours that have received the most attention in marketing (Netemeyer et al., 1997; Podsakoff \& MacKenzie, 1994) and management literature (Lau, 2002; Organ \& Ryan, 1995) are OCBs. Managers are trying to find new ways of inculcating citizenship behavior in employees which encompasses active participation, involvement, and voluntary actions of the employees in managing their jobs (Sekiguchi, 2006; Vigoda \& Golembiewski, 2001).

Many researchers have referred to OCB as the voluntary and willingness behavior (beyond job duties), performed by the individual to help the organization to achieve its goals. OCB includes task performance, doing challenging tasks, feeling oneself as a part of the organization, social support for other colleges, transferring knowledge, defending the organization, proposing solution and suggestions to enhance the organization performance and thinking about innovation and entrepreneurship within the organization (Morrison \& Robinson, 1997). Paternalistic leaders often emphasize on collective task accomplishment, learning by sharing 
experiences, and delegating authority which fosters employee's performance (Daft, 2001). Thus, paternalistic leadership builds a work environment in which employees' sense of motivation, meaning, inspiration, self-management help them to display organizational citizenship behaviour (Wat \& Shaffer, 2005).

This style of leadership prepares employees to take more responsibility and enhances beliefs about their capabilities to help others and become citizens of organizations (De Jong \& Den Hartog, 2007; Hughes, Ginnett, \& Curphy, 1999). Paternalistic leaders increase the involvement of the employees in helping behaviors, altruism, courtesy, sportsmanship and extra role behaviors. However when leaders deal their subordinates with authoritarian paternalistic style, OCB decreases on individual as well as organization level (Raja, Johns \& Ntalianis, 2004). According to the descriptions above, the following hypothesis can be stated

Hypothesis 2: Paternalistic leadership influences OCBI and OCBO.

H2a: Moral paternalistic leadership positively influences OCBI and OCBO.

H2b: Authoritarian paternalistic leadership negatively influences OCBI and OCBO.

\section{Research Method}

\subsection{Participants and Procedures}

The sample of our study was drawn from employees and their leaders by using survey methodology. The respondents were from thirteen public sector universities of Pakistan. We collected data from multiple universities for better and deeper understanding of the relationship structure among paternalistic leadership, organizational commitment and OCB. The anonymity and confidentiality of this survey was ensured to employees. We started by fixing appointments with deans of different departments. A request was made to the deans of participating universities to announce the purpose of the survey to their employees which is related to a delicate subject i.e. paternalistic leadership. The study included employees and their direct leaders from every department of these universities. Questionnaires were provided to employees who agreed to participate and were collected three weeks later by research assistants.

Employees completed a questionnaire on their perceptions of paternalistic leadership, organizational commitment and OCBO. Leaders provided ratings for each of their subordinates' OCBI. A total of 1100 questionnaires were distributed among the respondents out of which we got 798 filled questionnaires. The final sample consisted of $57 \%$ male participants. Majority of participants had master degree (77\%) whereas $16 \%$ had doctoral degrees. The average corporate tenure of the sample was 6.37 years.

\subsection{Measurement}

\subsubsection{Paternalistic Leadership (PL)}

Paternalistic leadership was measured using the PL Scale, developed by Cheng and his colleagues. The scale was taken from Cheng et al. (2004). Respondents rated their preferences anchored on a 5-point scale ranging from 1 (strongly disagree) to 5 (strongly agree).

\subsubsection{Organizational Commitment}

OC was measured using the 18-item Organizational Commitment Scale developed by Meyer \& Allen (1991). A 5-point response scale was used, ranging from "strongly disagree", (1) to "strongly agree”, (5). OC scale was factor analyzed using varimax rotation. Numerous rotations were made to obtain the best representation of the data. The results of the factor analyses indicate that the OC scale consisted of two factors - affective and continuance commitment. Cronbach's alpha of affective and continuance commitment were 0.76 and 0.83 respectively.

\subsubsection{Organizational Citizenship Behaviour}

Previous research, which is now widely accepted, indicates that Organ's (1988) OCB taxonomy can be distinguished into OCB Individuals (OCBI) and OCB Organization (OCBO) (Williams \& Anderson, 1991). OCBI is individuals' extra-role behavior toward others members in the organization such as altruistic and courtesy behavior. On the other hand, OCBO is individuals' discretionary behavior that supports organizational interests, and comprises behavioral dimensions such as sportsmanship, conscientiousness, and courtesy (Popper \& Mayseless, 2003). OCB scale was adopted from Organ (1988) OCB questionnaire which has good reliability and validity and has been widely applied in the study of organization citizenship behavior and the Cronbach's alpha of OCBI and OCBO were 0.77 and 0.76 respectively.

\section{Data Analysis and Results}

\subsection{Descriptive Analyses}

Table 1 presents means, standard deviations, and correlations among the study variables. The correlations procedure computes the pair wise associations for a set of variables and displays the results in a matrix. By looking at the correlation matrix between the constructs we can understand that MPL is the most correlated element with AC. The correlation of 0.79 between these two factors shows that a little change in the MPL has a major influence on the affective commitment of the teacher towards his/her university. The next relationship which is more important is the OCBO and APL. The next factor which is more important is APL with a correlation of 0.63 which shows a strong relationship with OCBO. Thus the teachers who are treated authoritatively, autocratically and with centralized management structures are reluctant to display citizenship behavior towards the organization and are less likely to defend and own their universities.

A negative correlation of -0.57 between CC and APL shows that when academic employees are treated with authority, coercion and rigidness they tend to lose sense of responsibility and sincerity towards the profession and organization. The results of the correlation matrix show that authoritarian style of paternalistic leadership decrease the commitment of the employees on all dimensions and also affect the citizenship behavior at individual as well as at the organization level. The table also shows that there 
exist a strong relationship between moral paternalism of boss and individual citizenship behavior of teachers.

Table 1. Means, Standard Deviation and Correlations

\begin{tabular}{|c|c|c|c|c|c|c|c|}
\hline $\mathrm{N}=798$ & Mean(SD) & 1 & 2 & 3 & 4 & 5 & 6 \\
\hline 1. Authoritarian paternalistic leadership & $4.83(0.24)$ & 1 & & & & & \\
\hline 2. Moral paternalistic leadership & $4.12(0.44)$ & 0.38 & 1 & & & & \\
\hline 3. Continuance commitment & $4.11(0.22)$ & $-0.57 *$ & $0.61 *$ & 1 & & & \\
\hline 4. Affective commitment & $3.66(0.54)$ & $-0.33^{*}$ & $0.71 *$ & 0.56 & 1 & & \\
\hline 5. OCBI & $3.86(0.13)$ & $0.27 *$ & $-0.23 *$ & 0.69 & 0.55 & 1 & \\
\hline 6. ОСВО & $3.66(0.37)$ & $0.21 *$ & $-0.63 *$ & $0.41 *$ & 0.31 & 0.49 & 1 \\
\hline
\end{tabular}

$*$ p-Value $<0.01$

\subsection{Confirmatory Factor Analysis}

The correlation matrix is a good predictor of the relationships but can only highlight that there is a relationship between the constructs and shows the degree to which all the variables are related, not the causal connections among the variables. To find the real causation, we need to investigate the direction of relationships as well as the effect of each sub dimension of PL on the other sub dimensions of OC and OCB. We also want to observe the overall impact of one construct over another. How do two dimensions of PL affect the dimensions of OC and OCB in the overall context?

Table 2. Results of Confirmatory Factor Analysis

\begin{tabular}{|c|c|c|c|c|}
\hline Constructs and Scale items & Loading & CR & AVE & $\boldsymbol{\alpha}$ \\
\hline Authoritarianism paternalistic leadership (APL) & & 0.78 & 0.47 & 0.81 \\
\hline My supervisor doesn’t leak any information to us. & 0.57 & & & \\
\hline supervisor often brings me much pressure while I am working with him/her. & 0.61 & & & \\
\hline My supervisor exercises strict discipline over subordinates. & 0.68 & & & \\
\hline My supervisor always reprimands us when the task isn't completed. & 0.73 & & & \\
\hline My supervisor's suggestion is always the final decision of the meeting. & 0.76 & & & \\
\hline Moral paternalistic leadership (MPL) & & 0.72 & 0.38 & 0.73 \\
\hline My supervisor is decent, and doesn't gain private profit through privilege. & 0.75 & & & \\
\hline My supervisor treats us impartially and selflessly. & 0.81 & & & \\
\hline My supervisor doesn't take the credit for my achievements and contributions for himself/herself. & 0.58 & & & \\
\hline My supervisor won’t make contacts or get his/her interests through the back door. & 0.69 & & & \\
\hline My supervisor employs people according to their virtues. & 0.61 & & & \\
\hline My supervisor often disciplines him/her, and always takes the lead. & 0.76 & & & \\
\hline My supervisor is the good example to us. & 0.65 & & & \\
\hline Continuance Commitment & & 0.79 & 0.54 & 0.76 \\
\hline I am not afraid of what might happen if I quit my job without having another one lined up. & 0.76 & & & \\
\hline It would be very hard for me to leave my organization right now, even if I wanted to. & 0.79 & & & \\
\hline Too much in my life would be disrupted if I decided to leave my organization now. & 0.83 & & & \\
\hline It wouldn't be too costly for me to leave my organization now. & 0.87 & & & \\
\hline Right now, staying with my organization is a matter of necessity as much as desire. & 0.71 & & & \\
\hline I feel that I have very few options to consider leaving this organization & 0.59 & & & \\
\hline One of the few serious consequences of leaving this organization would be the scarcity of available alternatives. & 0.67 & & & \\
\hline One of the major reasons I continue to work for this organization is that leaving would require sacrifice. & 0.66 & & & \\
\hline Affective Commitment & & 0.88 & 0.58 & 0.83 \\
\hline I would be very happy to spend the rest of my career with this organization. & 0.83 & & & \\
\hline I do not feel 'emotionally attached' to this organization. & 0.75 & & & \\
\hline This organization has a great deal of personal meaning for me. & 0.72 & & & \\
\hline I do not feel a 'strong' sense of belonging to my organization. & 0.78 & & & \\
\hline I do not feel like 'part of the family' at my organization. & 0.63 & & & \\
\hline I enjoy discussing about my organization with people outside it. & 0.21 & & & \\
\hline I really feel as if this organization's problems are my own. & 0.74 & & & \\
\hline I think that I could easily become as attached to another organization as I am to this one. & 0.31 & & & \\
\hline OCB Individuals (OCBI) & & 0.73 & 0.48 & 0.71 \\
\hline This employee obeys company rules and regulations even when no one is watching. & 0.73 & & & \\
\hline This employee believes in giving an honest day's work for an honest day's pay. & 0.83 & & & \\
\hline This employee is mindful of how his/her behavior affects other people's jobs. & 0.72 & & & \\
\hline This employee helps others who have heavy workloads. & 0.63 & & & \\
\hline This employee helps orient new people even though it is not required. & 0.77 & & & \\
\hline This employee is proud to tell others that /she is part of this organization. & 0.86 & & & \\
\hline OCB Organization (OCBO) & & 0.75 & 0.55 & 0.73 \\
\hline I defend my company when someone talks negative about it. & 0.68 & & & \\
\hline If my organization is going through hard time, I will stay with the organization. & 0.72 & & & \\
\hline $\begin{array}{l}\text { If an operation is consuming the organization resources and it is not my direct responsibility, I talk about it with } \\
\text { management. }\end{array}$ & 0.55 & & & \\
\hline $\begin{array}{l}\text { I do invest personal time and effort for doing challenging and voluntary tasks. } \\
\chi 2=1466.08, \mathrm{df}=833, \chi 2 / \mathrm{df}=1.76, \mathrm{RMSEA}=0.079, \mathrm{GFI}=0.96 \\
\mathrm{CFI}=0.97, \mathrm{NFI}=0.98, \mathrm{NNFI}=0.97\end{array}$ & 0.64 & & & \\
\hline
\end{tabular}


On consideration of multivariable, we first adopted the software LISREL 8.70 for a Confirmatory Factor Analysis on the conceived measurement models mentioned above. M1 was a baseline two-factor model of paternalistic leadership; M2 was a baseline two-factor model of OC; M3 was a baseline two-factor model of OCB. This study chose several parameters such as $x 2 / d f$, RMSEA, NFI, IFI, CFI, TLI, to test the whole fitting degree. The results were shown in Table 3. The values of $x 2 / d f$ for M1, M2 and M3 all outnumbered 3, RMSEA was also little exceeding 0.05 , however, the index numbers of NFI, TLI, IFI, GFI were all above 0.70 , which indicated that, they were still in the scope of acceptance. Table 2 shows that the study constructs had acceptable reliability coefficient and all the items loaded sufficiently. It also reflected the values of average variance extracted which were also within the range of acceptability.

The hypothesized relationships were tested using the multiple regression analysis using SPSS. Properties of the causal paths, including standardized path coefficients and $t$ values were used to test the hypotheses and are shown in Table 3. The path coefficient from MPL to AC is significantly positive $(\beta=0.739, t$-value $=5.385)$, thus the hypothesis that MPL positively affects AC is supported. Similarly, MPL has a significant positive effect on the CC $(\beta=0.417, \mathrm{t}$-value $=7.483, \mathrm{p}<0.001)$, hence the hypothesis that MPL positively affects AC and CC (H1a) is supported.

Table 3. Results of fit test on PL, OC and OCB

\begin{tabular}{lcccccccc}
\hline \multicolumn{1}{c}{ Model } & $\boldsymbol{\lambda}^{\mathbf{2}}$ & $\mathbf{d f}$ & $\boldsymbol{\lambda}^{\mathbf{2}} \mathbf{d f}$ & RMSEA & GFI & CFI & NFI & NNFI \\
\hline M1: Paternalistic leadership & 2468.16 & 857 & 2.88 & 0.068 & 0.91 & 0.91 & 0.92 & 0.92 \\
M2: Organizational Commitment & 1872.3 & 790 & 2.37 & 0.063 & 0.92 & 0.92 & 0.94 & 0.94 \\
M3: OCB & 1603.44 & 786 & 2.04 & 0.07 & 0.94 & 0.94 & 0.97 & 0.97 \\
\hline
\end{tabular}

The path coefficients from APL to AC and CC show significant negative relationships $(\beta=-0.378, t$-value $=4.225$, $\mathrm{p}<0.001),(\beta=-0.317, t$-value $=4.365, \mathrm{p}<0.001),(\beta=-$ 0.183 , respectively, hence the hypothesis that APL negatively affects AC and CC (H1b) is supported. The path coefficients from MPL to OCBI and OCBO are positive and significant $(\beta=0.546, t$-value $=5.898, \mathrm{p}<$

$0.001),(\beta=0.583, t$-value $=4.649, \mathrm{p}<0.001)$, thus the
hypothesis (H2a) that MPL positively affects OCBI and OCBO are supported. Similarly APL has negative effect on OCBI $(\beta=-0.486, t$-value $==5.217, \mathrm{p}<0.001)$ as well as OCBO $(\beta=-0.353, t$-value $=-6.388, p<0.001)$, hence supporting H2b.

Table 4. Results of regression analysis

\begin{tabular}{|c|c|c|c|c|}
\hline \multirow[t]{3}{*}{ Independent variable } & \multicolumn{4}{|c|}{ Dependent variable } \\
\hline & \multicolumn{2}{|c|}{ Step 1} & \multicolumn{2}{|c|}{ Step 2} \\
\hline & Affective commitment & Continuance commitment & OCBI & OCBO \\
\hline Moral paternalistic leadership & .739 & .417 & .546 & .583 \\
\hline Authoritarian paternalistic leadership & -.378 & -.317 & -.486 & .353 \\
\hline F-value & 86.8 & 74.6 & 134.6 & 163.2 \\
\hline $\mathrm{R}^{2}$ & .523 & .639 & .693 & .734 \\
\hline
\end{tabular}

The R2 was used to assess the model's overall predictive fit. We found that the proposed model explained a significant percentage of variance in PL $\left(\mathrm{R}^{2}=72.7 \%\right.$, F-value=266.21, $\left.\mathrm{p}<0.001\right)$. It means that about 73 percent of the variance in PL was accounted for by two dimensions of OC and two dimensions of OCB.

\section{Conclusion}

The commitment of teachers to the university is critical and is affected by leadership styles of management (Allen \& Meyer, 1990). In this sense, the results of the study indicated that moral paternalistic leadership had a strong effect on continuance commitment of the university teachers in Pakistan. This strong effect is due to the fact that teachers want freedom in designing courses, selecting teaching strategy, deciding learning outcomes and flexibility in choosing what to teach and how to teach and moral leaders foster the identification of the teachers with the universities and encourage them to emotional attachment and provide them with such flexibilities as desired by teachers. The teachers would consider the benevolent leader as a bond that ties them to the organization and increase their affective commitment.
A teacher who is affectively committed strongly identifies with the goals of the university, is emotionally attached to the students and head of departments and desires to remain a part of the organization. Such teacher commits to the organization because he/she wants to be a part of the university for long term. Moral role of leaders and their caring attitude towards the professional requirements of the teachers also help in increasing the citizenship behavior on individual level to a great deal. The teachers who have role models in the shape of dean or head of department speak good about the university, work honestly, follow the rules and regulations, inspire students and are more disciplined as compared to the teachers who are treated with authority. Also, it is indicated in the literature that most of the academic staff who work for moral paternalistic leaders would not leave their organizations for better payment or promotion opportunities. University teachers who are treated by their heads on moral principles usually show a higher level of individual citizenship behavior by helping students as well as their peers in learning new things and follow the rules and procedures of the institute with openness and willingness.

Future research in paternalistic leadership may consider the effect of perceived organizational justice, learning styles and innovative work behaviors as important 
variables because the concept of paternalism is closely related with individual liberty, equity, creativity and justice. The paternalistic leadership helps the employees to remain loyal to the organization. It will be a positive addition to the knowledge if future research tries to analyze the relationship between paternalistic leadership and the brain drain as well as on learning outcomes.

\section{References}

[1] Allen, N. J., \& Meyer, J. P. (2011). The measurement and antecedents of affective, continuance and normative commitment to the organization. Journal of Occupational Psychology, 63(1), 118.

[2] Anderman, E. M. (1991). Teacher Commitment and Job Satisfaction: The Role of School Culture and Principal Leadership.

[3] Asare, M. A. (2011). The Effects of Leadership Styles of Heads of Senior High Schools on Teachers' Job Performance in Selected Schools in the Kumasi Metropolis (Doctoral dissertation).

[4] Aycan, Z. (2006). Paternalism: Towards conceptual refinement and operationalization. In K. S. Yang, K. K. Hwang, \& U. Kim (Eds.), Indigenous and cultural psychology: Understanding people in context (pp. 445-466). New York, NY: Springer.

[5] Belisle, C. A. H. (2004). The teacher as leader: transformational leadership and the professional teacher or teacher-librarian. The Profession of Teacher-Librarianship, 73-79.

[6] Blackmore, J. (2005). The emperor has no clothes: Professionalism, performativity and educational leadership in high-risk postmodern times. Leadership, Gender and Culture in Education, 173-194.

[7] Blase, J., \& Anderson, G. (1995). The micro politics of educational leadership: From control to empowerment. Teachers College Press, Columbia University, 1234 Amsterdam Ave., New York, NY 10027.

[8] Brooks, F. P. (2003, February). What differences unionizing teachers might make on child care in the USA: Results from an exploratory study. In Child and Youth Care Forum (Vol. 32, No. 1, pp. 3-22). Springer Netherlands.

[9] Cerit, Y. (2010). The effects of servant leadership on teachers' organizational commitment in primary schools in Turkey. International Journal of Leadership in Education, 13(3), 301-317.

[10] Chan, S. C., Huang, X., Snape, E., \& Lam, C. K. (2012). The Janus face of paternalistic leaders: Authoritarianism, benevolence, subordinates' organization-based self-esteem, and performance. Journal of Organizational Behavior, 34, 108-128.

[11] Chen, Z. X., Tsui, A. S., \& Farh, J. L. (2002). Loyalty to supervisor vs. organizational commitment: Relationships to employee performance in China. Journal of Occupational and Organizational Psychology, 75(3), 339-356.

[12] Cheng, B. S., Chou, L. F., Wu, T. Y., Huang, M. P., \& Farh, J. L. (2004). Paternalistic leadership and subordinate responses: Establishing a leadership model in Chinese organizations. Asian Journal of Social Psychology, 7(1), 89-117.

[13] Chou, Y. C. (2006). A Study on the Relationship Between Principal's Paternalistic Leadership and Teachers' Organizational Citizenship Behavior in Elementary School.

[14] Chu, P. C. \& Hung, C. C. (2009). The Relationship of Paternalistic Leadership and Organizational Citizenship Behavior: The Mediating Effect of Upward Communication. Journal of Human Resource and Adult Learning, 5(2), 66-73.

[15] Cohen, A. (2006). The relationship between multiple commitments and organizational citizenship behavior in Arab and Jewish culture. Journal of Vocational Behavior, 69(1), 105-118.

[16] Cohen, A. (2007). An examination of the relationship between commitments and culture among five cultural groups of Israeli teachers. Journal of Cross-Cultural Psychology, 38(1), 34-49.

[17] Collins, M. D. (2010). The effect of psychological contract fulfilment on manager turnover intentions and its role as a mediator in casual environment. International Journal of Hospitality Management, 29, 736-742.

[18] Coyle, J.A. \& Neuman, J.H. (2004). The psychological contract and individual differences: The role of exchange and creditor ideologies. Journal of Vocational Behavior, 64 (1), 150-164.
[19] Dabos, G. E., \& Rousseau, D. M. (2004). Mutuality and reciprocity in the psychological contracts of employees and employers. Journal of Applied Psychology, 89(5), 52-72.

[20] Daft, R. L. (2001). The leadership experience. Fort Worth, TX: Harcourt College Publishers.

[21] De Jong, J. P., \& Den Hartog, D. N. (2007). How leaders influence employees' innovative behaviour. European Journal of Innovation Management, 10(1), 41-64.

[22] Eden, D. (1998). The paradox of school leadership. Journal of educational administration, 36(3), 249-261.

[23] Erben, G. S., \& Güneşer, A. B. (2008). The relationship between paternalistic leadership and organizational commitment: Investigating the role of climate regarding ethics. Journal of Business Ethics, 82(4), 955-968.

[24] Farh, J. L., \& Cheng, B. S. (2000). Paternalistic leadership in Chinese organizations: A cultural analysis. Indigenous Psychological Research in Chinese Societies, 13, 127-80.

[25] Feather, N. T., \& Rauter, K. A. (2004). Organizational citizenship behaviors in relation to job status, job insecurity, organizational commitment and identification, job satisfaction and work values. Journal of occupational and organizational psychology, 77(1), 8194.

[26] Foster, L. (2005). The practice of educational leadership in African American communities of learning: Context, scope, and meaning. Educational administration quarterly, 41(4), 689-700.

[27] Geijsel, F., Sleegers, P., Leithwood, K., \& Jantzi, D. (2003). Transformational leadership effects on teachers' commitment and effort toward school reform. Journal of Educational Administration, 41(3), 228-256.

[28] Gwavuya, F. (2011). Leadership Influences on other communityfunded college or education institutions: Turnover Intentions of academic staff in tertiary education. Academic Leadership Online Journal. 9(2), 345-363.

[29] Hakanen, J. J., Bakker, A. B., \& Schaufeli, W. B. (2006). Burnout and work engagement among teachers. Journal of school psychology, 43(6), 495-513.

[30] Harris, A. (2004). Distributed Leadership and School Improvement Leading or Misleading? Educational Management Administration \& Leadership, 32(1), 11-24.

[31] Henderson, G. (2008). Leadership experiences of male AfricanAmerican secondary urban principals: The impact of beliefs, values and experiences on school leadership practices (Doctoral dissertation, Cleveland State University).

[32] Huery, R. Y., Hsin, K. C. \& Chiou, C. (2008). The Influences of paternalistic leadership, job stress, and organizational commitment on organizational performance: An empirical study of policemen in Taiwan. The Journal of International Management Studies, 3(2), 85-91.

[33] Irawanto, D. W. (2011). Exploring paternalistic leadership and its application to the Indonesian context: a dissertation presented in partial fulfilment of the requirement for the degree of Doctor of Philosophy in cross-cultural leadership at Massey University, Palmerston North, New Zealand (Doctoral dissertation).

[34] Janelle E. W., Jon, W. P. (2010). Turnover intentions: Do leadership behaviors and satisfaction with the leader matter?.Team Performance Management 17(1/2), 23-40.

[35] Joo, B., \& Park, S. (2010). Career satisfaction, organizational commitment, and turnover intention: The effects of goal orientation, organizational learning culture and developmental feedback. Leadership and Organization Development Journal, 31(6), 482-500.

[36] Kamper, G. (2008). A profile of effective leadership in some South African high-poverty schools. South African Journal of Education, 28(1), 1-18.

[37] Kurnianingsih, S., Yuniarti, K. W., \& Kim, U. (2012). Factors influencing trust of teachers among students. International Journal of Research Studies in Education, 1(2).

[38] Law, W. W. (2009). Culture and school leadership in China: Exploring school leaders' views of relationship-and rule-based governance.

[39] Lin, M. Q. (2005). Intellectual capital, sharing organizational culture and organization managerial performance: An empirical investigation. Management Review, 24(1), 55-81.

[40] Liu, J., Siu, O. L., \& Shi, K. (2010). Transformational Leadership and Employee Well-Being: The Mediating Role of Trust in the Leader and Self-Efficacy. Applied Psychology, 59(3), 454-479. 
[41] Mascall, B., Leithwood, K., Straus, T., \& Sacks, R. (2008). The relationship between distributed leadership and teachers' academic optimism. Journal of Educational Administration, 46(2), 214-228.

[42] Meyer, J. P., Stanley, D. J., Herscovitch, L., \& Topolnytsky, L. (2002). Affective, continuance, and normative commitment to the organization: A meta-analysis of antecedents, correlates, and consequences. Journal of Vocational Behavior, 61(1), 20-52.

[43] Militello, M., \& Berger, J. B. (2010). Understanding educational leadership in North-west China. International Journal of Leadership in Education, 13(2), 185-202.

[44] Min, W., Xu, H., Jiuping, X., Hong, Y., \& Kan, S. (2007) Comparative study of transactional, transformational, and paternalistic leadership behaviors and leadership mechanism. Science Research Management, 3, 25-36.

[45] Morrison, E. W., \& Robinson, S. L. (1997). When employees feel betrayed: A model of how psychological contract violation develops. Academy of Management Review, 226-256.

[46] Mudulia, A. M. (2012). The Impact of Head Teachers' Administrative Factors on Performance in Secondary School Science Subjects in Eldoret Municipality, Kenya. Journal of Emerging Trends in Educational Research and Policy Studies (JETERAPS), 3(4), 514-522.

[47] Organ, D. W., \& Ryan, K. (1995). A meta-analytic review of attitudinal and dispositional predictors of organizational citizenship behavior. Personnel psychology, 48(4), 775-802.

[48] Pasa, S. F., Kabasakal, H., \& Bodur, M. (2001). Society, organizations, and leadership in Turkey. Applied Psychology: An International Review, 50(7), 559-589.

[49] Pellegrini, E. K., \& Scandura, T. A. (2006). Leader-member exchange (LMX), paternalism, and delegation in the Turkish business culture: An empirical investigation. Journal of International Business Studies, 37(2), 264-279.

[50] Pellegrini, E. K., \& Scandura, T. A. (2008). Paternalistic leadership: A review and agenda for future research. Journal of Management, 34(3), 566-593.

[51] Pellegrini, E. K., Scandura, T. A., \& Jayaraman, V. (2010). Crosscultural generalizability of paternalistic leadership: An expansion of leader-member exchange theory. Group \& Organization Management, 35(4), 391-420.

[52] Popper, M., \& Mayseless, O. (2003). Back to basics: Applying a parenting perspective to transformational leadership. The Leadership Quarterly, 14(1), 41-65.

[53] Raja, U., Johns, G., \& Ntalianis, F. (2004). The impact of personality on psychological contracts. Academy of Management Journal, 47 (3), 350-367.
[54] Rehman, M. \& Afsar, B. (2012). The impact of Paternalistic Leadership on Organization Commitment and Organization Citizenship Behavior.

[55] Rhea, B. (1968). Institutional paternalism in high school. The Urban Review,2(4), 13-16.

[56] Robinson, S. L., \& Rousseau, D. M. (1994). Breaching the psychological contract: Not the exception but the norm. Journal of Organizational Behavior, 15, 245-259.

[57] Sagie, A. (1998). Employee absenteeism, organizational commitment, and job satisfaction: Another look. Journal of Vocational Behavior, 52(2), 156-171.

[58] Schriesheim, C. A., Neider, L. L., \& Scandura, T. A. (1998). Delegation and Leader-Member Exchange: Main Effects, Moderators, and Measurement Issues. Academy of Management Journal, 41(3), 298-318.

[59] Schroeder, J. (2011). The Impact of Paternalism and Organizational Collectivism in Multinational and Family-owned Firms in Turkey (Doctoral dissertation, University of South Florida).

[60] Soylu, S. (2011). Creating a family or loyalty-based framework: The effects of paternalistic leadership on workplace bullying. Journal of business ethics, 99(2), 217-231.

[61] Suazo, M. M. (2009). The mediating role of psychological contract violation on the relations between psychological contract breach and work-related attitudes and behaviors. Journal of Managerial Psychology, 24(2), 136-160.

[62] Sun, L. H. (2010). The effects of Paternalistic Leadership, Organization Culture, Job Stress and Organization Performance-A case of study for Elementary Schools in Changhua County.

[63] Turnley, W.H., Bolino, M.C., Lester, S.W., \& Bloodgood, J.M.(2003). The impact of psychological contract fulfillment on the performance of in-role and organizational citizenship behaviors. Journal of Management, 29 (2), 187-206.

[64] Van, E. (2006). Autocratic Leadership Around the Globe Do Climate and Wealth Drive Leadership Culture?. Journal of CrossCultural Psychology,37(1), 42-59.

[65] Wang, H., Law, K. S., Hackett, R. D., Wang, D., \& Chen, Z. X (2005). Leader-member exchange as a mediator of the relationship between transformational and leadership and followers' performance and organizational citizenship behavior. Journal of Applied Psychology, 48(3), 420-432.

[66] Wat, D., \& Shaffer, M. A. (2005). Equity and relationship quality influences on organizational citizenship behaviors: The mediating role of trust in the supervisor and empowerment. Personnel Review, 34(4), 406-422.

[67] Wren, D. A. (2005). The history of management thought. Hoboken, NJ: Wiley. 